\title{
COMPETING WORKERS' RIGHTS TO REPRESENT WORKERS AS VIET NAM JOINS FREE TRADE AGREEMENTS (CPTPP, EVFTA) - A CHALLENGE FROM VIET NAM'S TRADE UNIONS
}

\author{
LOS DERECHOS DE LOS TRABAJADORES EN COMPETENCIA DE \\ REPRESENTAR A LOS TRABAJADORES MIENTRAS VIET NAM SE UNE A LOS \\ ACUERDOS DE LIBRE COMERCIO (CPTPP, EVFTA): UN DESAFÍO DE LOS \\ SINDICATOS DE VIETNAM
}

\author{
Huu Nguyen-Duc ${ }^{1} *$ (D). \\ 1. Vietnam Trade Union University. huund@dhcd.edu.vn
}

*Corresponding author: Huu Nguyen-Duc, email: huund@dhcd.edu.vn

\begin{abstract}
Economists expect that CPTPP, together with the EU-Vietnam Free Trade Agreement (FTA), will bring enormous economic benefits to Vietnam, by increasing the price competitiveness of Vietnam's exports in key markets and boosting foreign direct investment (FDI), promoting economic development and creating millions of jobs, including in small and medium-sized enterprises. More importantly, CPTPP will help facilitate domestic reforms in many areas and build an environment for a competitive economy. The purpose of this article is to clarify the impact of free trade agreements on Vietnamese trade unions, which are considered exclusive in representing workers throughout the territory of Viet Nam but will no longer play this role when Viet Nam joins next-generation trade agreements.
\end{abstract}

Keywords: Free trade agreement; CPTPP- EVFTA; Trade Union; Vietnam.

Cómo citar:

Nguyen-Duc, Huu. (2021). Competing workers' rights to represent workers as Viet Nam joins free trade agreements (CPTPP, EVFTA) - a challenge from Viet Nam's trade unions. Revista de Investigaciones Universidad del Quindio, 33(2), 153-162. https://doi.org/10.33975/riuq.vol33n2.568 


\section{RESUMEN}

Los economistas esperan que CPTPP, junto con el Tratado de Libre Comercio (TLC) UE-Vietnam, traerá enormes beneficios económicos a Vietnam, al aumentar la competitividad de precios de las exportaciones de Vietnam en mercados clave e impulsar la inversión extranjera directa (IED), promoviendo el desarrollo económico y creando millones de puestos de trabajo, incluso en las pequeñas y medianas empresas. Más importante aún, el CPTPP ayudará a facilitar las reformas internas en muchas áreas y creará un entorno para una economía competitiva. El propósito de este artículo es aclarar el impacto de los acuerdos de libre comercio en los sindicatos vietnamitas, que se consideran exclusivos en la representación de los trabajadores en todo el territorio de Vietnam, pero que ya no desempeñarán este papel cuando Vietnam se una a los acuerdos comerciales de la próxima generación.

Palabras clave: Tratado de libre comercio; CPTPP- EVFTA; Sindicato; Vietnam.

\section{INTRODUCTION}

CPTPP was signed with the participation of 11 countries: Vietnam, Australia, Brunei, Canada, Chile, Japan, Malaysia, Mexico, New Zealand, Peru and Singapore. CPTPP essentially retains the contents of the old TPP but allows member states to postpone some obligations to ensure balance in the new context with the high quality of the Agreement. (Lu, 2018) Therefore, the nature and quality of the Agreement is shown in two additional words: Comprehensive and Progressive, which is the common goal for the inclusive nature of the TPP. CPTPP does not have the United States, but the participating group accounts for about $13 \%$ of the total global GDP. Participating in this Agreement, Vietnam can promote the export of goods, attract foreign investment in countries such as Japan, Australia, Canada, Mexico are important partners in trade and investment. Participation in this agreement creates competition with a wellventilated business and investment environment and thereby will also bring positive motivation for development. According to the Ministry of Planning and Investment, Vietnam's GDP will increase by about $1.32 \%$, exports will increase by $4 \%$. Chapter 19 on Labour of the CPTTP is based on the 1998 ILO Declaration. This chapter also shows the link between the implementation of the 1998 ILO Declaration and trade conditions within a certain time frame, including possible sanctions. According to the assessment, Vietnam will be a country that receives many benefits when participating in CPTPP. (Maliszewska et al., 2020) Opportunitiesare huge, but to take advantage of the opportunity requires a lot of effort from theGovernment and Vietnamese businesses themselves. When CPTPP is implemented, Workers and Trade Union organizations in Viet Nam will be strongly impacted on jobs, organizational models and activities.

Labour rights were one of the main issues in the final round of CPTPP negotiations before signing. The new generation free trade agreement (FTA) is characterized by a great emphasis on labor rights, as well as protecting the sustainability of the environment, helping workers and businesses enjoy economic benefits fairly. Cptpp requires all participating countries to pass and uphold the rights set out in the 1998 Declaration of the International Labour Organization (ILO) in law, institutions and practice, all ILO member states, including Viet Nam, must respect these rights. These are considered rights recognized worldwide in modern society. However, Viet Nam has yet to ratification of three fundamental conventions (Conventions 87, 98 and 105) concerning freedom of association, the right to collective negotiation and the elimination of forced labour. (Khan et al., 2021) Achieving this 
requires Viet Nam to develop and improve its legal framework and industrial relations system, to serve the needs of workers, businesses and society, towards political stability and common prosperity. With a better legal system and investment environment, Vietnamese workers will have more job opportunities, career choices, working conditions, incomes and lives to be improved, protected and equal to workers in other countries. In order to take advantage of cptpp opportunities, Viet Nam's workforce needs to be trained to have vocational skills and information technology, especially in the industrial phase 4.0. If the requirements are not met, the risk of not having a job, unemployment of workers is great, it is always possible to reach individuals, groups of people, even businesses. (Zhu \& Fahey, 2000)

Participating in CPTPP, EVFTA is acceptable in the near future Viet Nam's trade unions will have to compete with workers' representative organizations (employees), something unprecedented. Up to now, Vietnam Trade Union has been the only organization representing workers, performing 3 functions of trade union: representing and protecting employees; participate in management and supervision; educating, propagating workers and participating in the performance of political tasks of the country, branches and enterprises. The issue of competition and attraction of trade union members is inevitable with Vietnam Trade Union and workers' representative organizations established in enterprises. (T Pringle / Clarke, 2010) Viet Nam's trade unions will have difficulty establishing trade unions at the base and developing trade unions, resources to ensure activities will be shared and reduced, the environment of trade union activities will also change greatly due to complicated industrial relations. Vietnam's trade unions currently have many advantages but there are also many disadvantages in terms of organizational model, administrative activities, pure movement organization, slow to adapt to the new situation. When an employee representative organization is established at the facility with unusual statements, it may initially attract workers to participate, even to move the old organization (Vietnam Trade Union) to join this new organization. This is the risk of losing trade union members, difficult to develop new trade union members of Vietnam Trade Union in the coming time. (Duc Huu, 2020)

\section{LITERATURE REVIEW}

Determining the position and role of trade unions in the process of industrialization, modernization and international economic integration is not only a matter of consciousness and ideology but also a pressing practical issue to create conditions for trade unions to promote their capacity in the political system in Vietnam; actively participate in solving practical problems related to the lives of workers, public employees and labor, implementing economic growth associated with progress and social justice. (Clarke et al., 2007)

The Constitution of the Socialist Republic of Vietnam affirmed that "Trade unions are sociopolitical organizations of the working class and of workers together with State agencies, economic organizations, social organizations to take care of and protect the rights of cadres, workers, public employees and other workers; participate in state and social management, participate in inspection and supervision of activities of State agencies and economic organizations; educating cadres, workers, public employees and other workers to build and protect the Fatherland" (Article 10 of the 2013 Constitution). (Them Do, 2016)

Trade unions are broad socio-political organizations of the working class and of workers, established on a voluntary basis, being members of the political system of Vietnamese society, under the leadership of the Communist Party of Vietnam; representing cadres, civil servants, public employees, workers and other workers (here below referred to as employees), together with state agencies, economic organizations and social organizations to take care of and protect the legitimate rights and interests of employees; 
participate in state management, socio-economic management, participate in inspection, inspection and supervision of activities of state agencies, organizations, units and enterprises; propagate and mobilize workers to study to improve their professional qualifications and skills, law enforcement, construction and defense of the socialist Fatherland of Vietnam. (Article 1 of the 2012 Trade Union Law) (Justice, 2013)

Thus, trade unions are professional sociopolitical organizations, which are the largest masses of the working class and the working people. Trade unions appear when workers are aware of collective strength and take care of protecting their own rights. (Asia, 2019; Conference et al., 2008) The trade union was originally just an organization created to fight and limit the exploitation of the owners, not an organization with as much power as it is today. The development of trade unions is associated with the growth of the working class, with the development of industry, technology and the cohesion of the owners. It is in that development that trade union activities are also promoted and gradually gain an important position in the system of social organizations, as well as in the lives of workers. From a place that is only admitted on a narrow scale, today trade unions have been recognized throughout society.

The amendment of the Law on Trade Union is an objective inevitable demand, meeting the activities of trade union organizations in the period of promoting industrialization, national economic integration, international economic integration when participating in free trade agreements such as CPTPP, EVFTA(TRANSITION, 2018) . Despite this, developing current Trade Union legislation is a difficult task due to the rapidly growing situation of various types of enterprises, the diversity of industrial relations and the requirement for effective enforcement of trade union rights; the functions and tasks of trade unions are wide, spread, lack of concentration, have certainly affected the quality and efficiency of trade union activities in the field of representation, protection of legal and legitimate rights and interests of employees ...

In the context that the Law on Trade Union (2012) needs to be adjusted a number of provisions to timely institutions of the Views of the Communist Party of Vietnam on the completion and development of the socialistoriented market economy and "Continuing to build the Vietnamese worker class in the period of promoting the $\mathrm{CNH}$ and the Country's People's Council". CPTPP and EVFTA demand that Viet Nam respect and promote the 1998 ILO Declaration, in particular Convention 87 on Freedom of Association and Convention 98 on the Right to Collective Negotiation. (Chan, 2019; Martin, 2010; Rights, 2019; TRANSITION, 2018) In short, it requires trade unions to be unions - in other words, it requires trade unions to be workers' organizations, as they are in most ILO member countries.

Trade union rights are workers' rights. In most ILO member countries, there are legal provisions ensuring trade union independence from employers, free from interference or discrimination by employers and union autonomy in managing their own internal issues, free from excessive administrative interference, in accordance with the rules set by national law and in accordance with international labour standards. And it is the universal rules and principles of trade unions and industrial relations, as shown in the 1998 ILO Declaration, which are required by CPTPP and EVFTA(Thi Tam, 2021)

\section{RESULT}

In the current conditions in Vietnam, there are many new factors, which have a many dimensional impact on the development of Trade Union laws. Problems with economic management mechanisms; the position of the employee; diversity of employers; the innovation of the system of trade union organization, international integration and the impact of the 
4th scientific revolution (4.0). The above factors set the requirements in the development of trade union legislation must innovate strongly and comprehensively to affirm the position in society and the political system.

\section{Innovation of economic management mechanisms}

Re-developing social enterprise thinking and building social enterprises in Vietnam with the main goal of developing the production capacity of society, perfecting production relations in accordance with the conditions of the transition period to social enterprises, thereby improving people's lives ... That sets out the need to innovate economic management mechanisms. For the first time in the process of building social enterprises in Vietnam, there are many economic sectors, including: public economy, private and mixed economy. (Maliszewska et al., 2020) The private sector makes private enterprise appearance (including FDI enterprises). The need to protect the rights and interests of workers in new labor relations. Therefore, trade union law-building activities must be innovated to meet new needs.

The new management mechanism with a variety of forms of ownership entails many employers and management methods. Business mechanisms according to the principles of market economy, accounting and autonomy in parallel exist with the mechanism of orders, focus ... still exists as a testament to the old management mechanism in a division of state-enterprise. Distribution by labor has been confirmed more clearly, in fact, the main method of distribution, but interacts with the method of distribution by ownership. Accordingly, the interests of each subject are different and there may be collisions. The mechanism of operation of trade unions accordingly, both under the dominant impact, and must overcome the problems arising in the interaction of the new mechanism and the old mechanism. (Minh et al., 2020)
Figure 1. Viet Nam's export and import rankings in the global market

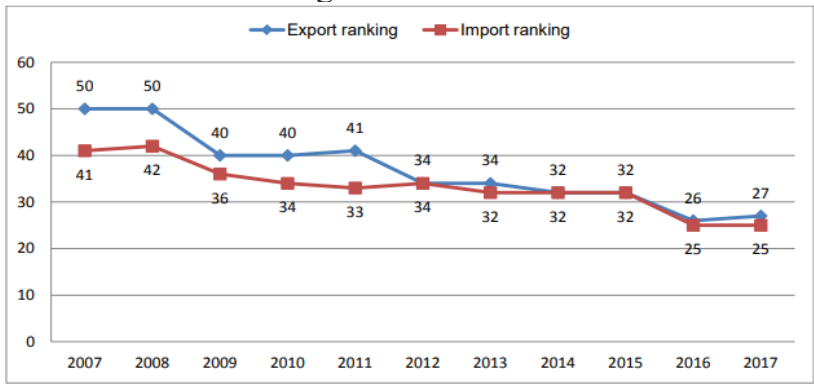

Source: Customs Statistical Yearbook of Import and Export, Viet Nam's General Customs Department (2018)

The legal system for to regulate and manage in the new mechanism also formed. About 600 laws and laws related to trade union organization and activities were born. In particular, "there are 10 types of legal regulations related to trade union activities in FDI enterprises (including the Law, Ordinances, Decrees, Circulars, Directives, Regulations, Decisions, Charters, Resolutions of the Executive Committee of Vietnam General Confederation of Labor and Enterprise Collective Labor Agreement) concerning 6 promulgating parties (National Assembly, Government, ministries, Vietnam General Confederation of Labor, Hanoi Confederation of Labor and parties in industrial relations in FDI enterprises). Understanding and applying the law becomes a self-requirement of trade union officials at the establishment. (Chan \& wang, 2004; Trinh, 2014)

Trade unions participating in state management contribute to stabilizing and developing enterprise production; ensuring jobs and incomes of employees; supervise and urge the full implementation of insurance, taxes ... The equal position of trade unions and the right to information about enterprises of employees become objective requirements, not only in the protection of workers' rights but also in the function of participating in management. (Ethics, 2005; Vo et al., 2010) In the process of international integration, Vietnamese enterprises and trade unions must also approach and participate in the implementation of a series of new issues. Enterprises are interested in labor 
productivity; rights and interests of employees; international standards and conventions, such as ISO, corporate social responsibility ... Trade unions well solve the issue of social consensus, bilateral and tri-party relations, handle industrial relations conflicts ... The international nature is gradually evident through the increasing requirements from the market in management, labor, environment ... with both businesses and trade unions. This is also a "pressure" and also a push to develop laws on trade unions on the completion of ports, contributing to building a democratic, fair and civilized society. (Genus \& Van Den Broek, 2013; Trinh \& kien, 2010)

\section{Position of workers in the period of industrialization, modernization and international integration}

The process of innovation has changed the relationship between workers and trade unions. A positive direction is a closer relationship between the rights and interests of members and the function of protecting employees of Trade Unions in resolving industrial relations situations. The opposite direction is whether the law on Trade Union protects its members' rights and interests and whether trade union members truly trust to delegate responsibility to Trade Unions as representatives of their rights or not. (Clarke / Pringle, 2007; Tim Pringle, 2013)

Both of these directions are affected by the requirement to promote industrialization and OS, namely the requirement for technological innovation, management methods, cultural qualifications, skills to access the regional and world markets ... Accordingly, Viet Nam's employees are gradually acquainted with the trend of socialization of production, labor intelligence, globalization of goods standards ... Many Vietnamese enterprises engaged in simple segments of global production (electronic assembly, textile, garment, seafood processing ...) also appeared a great demand for labor that does not require high skills. Therefore, there is still a fairly large percentage of employees who simply participate in a modern production process. This is especially true of the group of enterprises engaged in the assembly segment. (Review, 1951) In such enterprises, besides the group of workers with knowledge, skills and experience, the trade union at the establishment has a part of trade union members that has not shaped the industrial labor style, has not made a habit of coordinating work in the organization ... They are a simple labor group, the work is quite monotonous, the intensity of labor is high, low income, making this group of workers sometimes have the necessary over-responses. The complexity of trade union management also increases. (Khanh, 2014)

Figure 2: Trade union: Nation's industrial zone unions network established

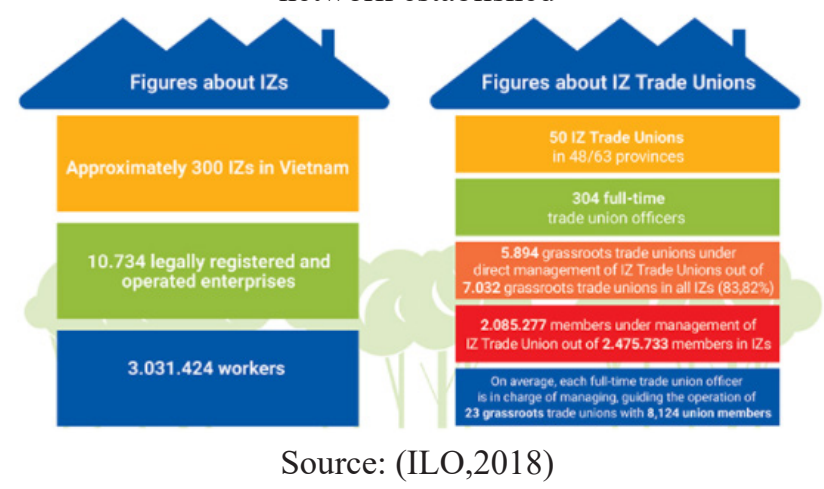

Along with industrial workers, Vietnamese workers have also gradually changed their industrial relations habits and behaviors. From strictly observing orders, complying with plans and organizations, employees turn to industrial labor behavior, considering the quality and progress of production, internal rules, collective labor agreements and higher brands of enterprises, national industrial brands are the values of professional culture. Issues that arise from labor relations are also legally resolved, by negotiating, dialogue or litigation measures, putting pressure on employers to achieve legitimate benefits for workers. (Science \& Science, 2011)

\section{Employer diversity}

The employer is one of the "two parties" of industrial relations in the enterprise and a partner 
of the current Trade Union. Employers differ in many aspects. In terms of nationality, besides the traditional group of Vietnamese coaches, the management team is foreigners and the group representing employers are CEOs who are not Vietnamese. Using foreign language skills to be able to have dialogues and discussions with partners is quite high and specific requirements for facility staff. (Tim Pringle, 2013)

Labor relations also appeared many other situations before. In the 1990s, labor relations were primarily about full enforcement of the rights recognized in laws, labor contracts, collective labor agreements. In recent years, issues related to benefits have appeared more and accounted for the majority in collective labor disputes. Collective labor disputes about benefits arise in very diverse practice, even if the parties in the labor relations do not violate legal provisions or collective labor agreements. These issues emerged from the actual situation, with which there was, no longer in accordance with the legal framework. Since then, there have been disagreements between the employees and employers. Often, employees ask employers to give them the benefits they think they deserve: bonuses, salary increases ... while employers believe that they have fulfilled their obligations and commitments. (Edwards et al., 2008; T Pringle / Clarke, 2010)

In order to resolve disputes, the legislative work of Trade Union must gather legal facts, formulate arguments for effective negotiation ... Also from the fact, when the need for benefits frequently appears and is acknowledged will tend to gradually be legal into rights. (Siu / Chan, 2014)This is the role of contributing to the development and improvement of trade union laws but also little discussed. Foreign partners (including employers and employees) often bring the traditions of their company and culture into Vietnam, including things that arenot suitable for Vietnamese workers. Therefore, there are many collisions due to cultural differences. Understanding the culture of partners to find similarities in behavior and contribute to building harmonious labor relations is also a natural requirement with Vietnamese employees today. Therefore, the development of trade union laws must take into account legal support, negotiation skills and encourage capacity building of trade union officials at all levels. (Arnold, 2012)

\section{The innovation of the trade union organization system}

For the domestic trade union system, the organization and operation of trade unions in our country are gradually moving from "tower shape" to combined with "network". Organizational tower is a 4-level trade union with the characteristics of superiors making decisions and directives; subordinates. The advantage is focus, unity, but the disadvantage is that information from top to bottom must go through many levels, leading to un timely. (Li, 2016) Policy: The upper trade union "towards the establishment" together solves problems and innovates the leadership method from administrative direction to direct and regularly supports and creates conditions for trade unions at the establishment to actively perform their tasks. That direction of organizational innovation is being implemented. The strengthening of the capacity, rights and relatively independent position for the trade union at the establishment of a "network" in which each stitch has a specific position and role. (Change, 2017)

\begin{tabular}{lcccc} 
Table 1 The Number of Trade Union Officers in Three Economic Hubs in South Vietnam \\
\hline & $\begin{array}{c}\text { Binh Duong } \\
\text { Industrial Zones } \\
\text { Trade Union }\end{array}$ & $\begin{array}{c}\text { Dong Nai } \\
\text { Industrial Zones } \\
\text { Trade Union }\end{array}$ & $\begin{array}{c}\text { Ho Chi Minh City } \\
\text { Industrial Zones } \\
\text { Trade Union }\end{array}$ \\
\hline \multirow{2}{*}{$\begin{array}{l}\text { No. of } \\
\text { full-time } \\
\text { officers }\end{array}$} & Technical officers & 3 & 5 & 12 \\
\cline { 2 - 5 } No. of enterprises & 6 & 7 & 6 \\
\cline { 2 - 5 } Administrative staff & 9 & 12 & 18 \\
\hline No. of workplace trade unions & 490 & 369 & 800 \\
\hline No. of workers & 318 & 350 & 724 \\
\hline No. of union members & 140,000 & 160,000 & 273,000 \\
\hline
\end{tabular}

Source: ILO, 2018

Relations with world trade union organizations and trade unions and trade unions in each country are also wider, multilateralized, more diversified. Actively integrating, willing to be 
friends and a reliable and responsible partner with international friends is also the foreign strategy of Vietnam Trade Union. Many experiences of trade unions in some areas that we are still surprised, such as: globalization, dealing with the problems of industrial relations in the market mechanism have been exchanged and learned. (Asia, 2019) New ways of doing things, new notions of sustainable employment, corporate social responsibility, collective labor agreements, negotiations on both sides ... are important grounds for the development of trade union legislation to ensure reasoning and practicality, meeting the activities of Vietnamese trade union organizations in current conditions.

\section{DISCUSSION}

The process of industrialization, modernization and international integration causes many problems with VietnamTradeUnion. Someforeign corporations and enterprises have many trade union organizations and consider trade unions as a policy partner with the state and a partnership with employers, when entering Vietnam can bring different notions. The Convention of the International Labour Organization (ILO), of which Viet Nam is a member, has a provision for "Freedom of Association"; The Trans-Pacific Partnership (CPTPP) is a commitment to "trade union freedom", while Viet Nam is maintaining a unified trade union system and the only one is the Viet Nam General Confederation of Labour... is a matter of concern, finding a solution. In particular, CPTPP will appear the phenomenon of "trade union competition" and the current Trade Union organization is forced to refresh itself if it does not want to become a "second choice".

The view is that if trade unions operateeffectively, boldly fight, speak up the voices and pressing emotions of employees, then the newly born trade union organizations will join the Vietnam Trade Union organization, creating more strength for Vietnamese trade union organizations. (Science, 2011) On the contrary, if trade unions operate superficially, ineffectively, do not fight for workers' rights or fight ineffectively, organizations of newly born trade unions will not join Vietnam Trade Union. They will link themselves to protect workers' rights. At that time, surely the current trade union organization was just a form, without real power. (Phuong Nguyen, 2016) This is a huge challenge. From the above factors, the work of developing trade union laws sets urgent requirements, which are:

Trade unions must innovate strongly and apply from trade unions at the same level to the central level. The law on trade unions ensures that the operation of trade unions at the local level must be truly innovated to meet the requirements set out in the new situation

Trade unions must aim to improve the capacity of employees. The concurrent mechanism of the local employees has also revealed many disadvantages. Professionalizing the staff is an important hint from practice.

\section{CONCLUSION}

In terms of integration and participation in free trade agreements such as CPTPP, EVFTA, trade unions are representatives to protect the legitimate rights of workers. When the law provides for trade unions together with State agencies, other economic organizations and social organizations to take care of and protect the rights of employees, participate in the examination and supervision of the enforcement of the provisions of law, the rights of trade unions shall be specified to different degrees. In practice, the application of the above provisions of the Law on Trade Union depends on many factors, including factors belonging to the practical operation capacity of the trade union organization itself. Therefore, Vietnam's trade union organization needs to restructure and innovate in the form and method of operation, truly representing the rights and interests of employees in the enterprise rather than an administrative management unit on labor as it is today. 


\section{REFERENCES}

1. Them Do, Kim. (2016). Vietnam's Disappointing New Constitution-The New Constitution Promises More of the Same: It's Time for the Public to Make Their Voices Heard. Papers.Ssrn. Com. https://papers.ssrn.com/sol3/papers.cfm?abstract_id $=2840360$

2. Arnold, D. (2012). Social Margins and Precarious Work In Vietnam. American Behavioral Scientist, 57(4), 468-487. https://doi.org/10.1177/0002764212466245

3. Asia, N. C.-T. U. and L. M. in the. (2019). 15 The reform of Vietnam trade union and the government's role since doi moi. Books.Google.Com. https://books.google.com/books?hl=vi\&lr $=\& \mathrm{id}=$ DlyvDwAAQBAJ\&oi $=$ fnd $\& p g=$ PT322 $\& \mathrm{dq}=$ Trade + Union + of + Vietnam\&ots $=$ yyiYUUW0 qJ\&sig=gfm-ifxtIDAEJ8C7Gqj-efI2kFs

4. Chan. (2019). Vietnam has Ratified ILO C98. How about China? International Union Rights, 26(3), 4. https://doi.org/10.14213/inteuniorigh.26.3.0004

5. Chan, A., \& Wang, H.-Z. (2004). The Impact of the State on Workers' Conditions: Comparing Taiwanese Factories in China and Vietnam. JSTOR. https://doi.org/10.2307/40023535

6. Change, Q. D.-D. (2017). The regional coordination of strikes and the challenge for union reform in Vietnam. Wiley Online Library. https://doi.org/10.1111/dech.12326

7. Chi, D. Q., \& Van Den Broek, D. (2013). Wildcat strikes: A catalyst for union reform in Vietnam? Journals.Sagepub.Com, 55(5), 783-799. https://doi.org/10.1177/0022185613491685

8. Clarke, S., Lee, C.-H., \& Chi, D. Q. (2007). From Rights to Interests: The Challenge of Industrial Relations in Vietnam. Journals.Sagepub.Com, 49(4), 545-568. https://doi. org $/ 10.1177 / 0022185607080321$

9. Simon Clarke \& Tim Pringle. (2009). Can party-led trade unions represent their members?. PostCommunist Economies, 21(1), 85-101, https://doi.org/10.1080/14631370802663679

10. Do, Quynh Chi. (2008). The challenge from below: Wildcat strikes and the pressure for union reform in Vietnam. Warwick.Ac.Uk. http://web.warwick.ac.uk/russia/ngpa/ChallengefromBelow. doc

11. Huu, N. (2020). FREEDOM OF ASSOCIATION UNDER THE CONTEXT OF VIETNAM'S PARTICIPATION IN THE COMPREHENSIVE AND PROGRESSIVE TRANS-PACIFIC PARTNERSHIP (CPTPP) AGREEMENT AND THE EUVIETNAM FREE TRADE AGREEMENT (EVFTA). International Journal of Social Science and Economic Research, 5(11), 3401-3413. https://doi.org/10.46609/IJSSER.2020.v05i11.008

12. Edwards, V., and, A. P.-T. U. in A. A. economic. (2008). 12 Trade unions in Vietnam. Books. Google. Com. https://books.google.com/books?hl=vi\&lr=\&id=BxzpdOA0wXMC\&oi=fnd\&pg=PA199\& $\mathrm{dq}=$ Trade + Union + of + Vietnam\&ots $=$ mmS4Xh8LH-\&sig $=$-twLbKc_fJqVaeZiXKd4IiUXajU

13. Wang, Hz. (2005). Asian Transnational Corporations and Labor Rights: Vietnamese Trade Unions in Taiwan-invested Companies. J Bus Ethics 56, 43-53. https://doi.org/10.1007/s10551-004-10347

14. Pringle T. (2013) Social Justice on the Shop Floor: Trade Union Reform in Russia, China and Vietnam. In: Howell J. (eds) Non-Governmental Public Action and Social Justice. Non-Governmental Public Action. Palgrave Macmillan, London. https://doi.org/10.1057/9781137309174_2

15. Khan, M. O., Aamir, M., \& Khan, M. A. (2021). Economic impact of UK joining Asia Pacific Trade pact CPTPP: A Global CGE Approach. Papers.Ssrn.Com. https://doi.org/10.2139/ssrn.3790232

16. Khanh, T. L. (2014). Trade Union Organizing Free from Employers' Interference: Evidence from Vietnam. 589 Southeast Asian Studies. 3(3). https://doi.org/10.20495/seas.3.3_589

17. Trinh, L. K. (2014). Application of international labour standards on the right to strike: the case of Vietnam. Biblio.Ugent.Be. Conference Paper https://biblio.ugent.be/publication $/ 4397890$

18. Li, X. (2016). Is classic dualist union model obsolete? Party-led trade unions in China, Vietnam, Cuba and Laos. ilpc.org.uk. https://www.ilpc.org.uk/Portals/7/2016/Documents/PaperUpload/ ILPC2016paper-Conference paper for ILPC 2016 in Berlin-Xiang Li_20160318_011159.pdf

19. Lu, S. (2018). 2018 Proceedings Evaluation of the Potential Impact of CPTPP and EVFTA on Vietnam's Apparel Exports: Are We Over-optimistic about Vietnam's Export Potential? In iastatedigitalpress.com. http://itaaonline.org

20. Maliszewska, M., Pereira, M., Osorio-Rodarte, I., \& Olekseyuk, Z. (2020). Economic and distributional Impacts of the EVFTA and CPTPP in Vietnam 1. https://www.gtap.agecon.purdue. edu/resources/download/9731.pdf 
21. Martin, M. (2010). US-Vietnam Economic and Trade Relations: Issues for the 111th Congress. https://apps.dtic.mil/sti/citations/ADA520585

22. Nga, L.T.V., Huy, D.T.N., Minh, D.N., Dat, P.M. 2020. European-Vietnam Free Trade Agreement (EVFTA) impacts on imports: a case study. Journal of Security and Sustainability Issues, 9(M), 56-68. http://doi.org/10.9770/jssi.2020.9.M(5)

23. Phuong Nguyen, B. (2016). THE STRATEGY OF TRADE UNION REVITALISATION IN VIETNAM. https://researchrepository.rmit.edu.au/view/delivery/61RMIT_INST/1224829554000 1341/13248407910001341

24. Pringle, T, \& Clarke, S. (2010). The challenge of transition: Trade unions in Russia, China and Vietnam. https://books.google.com/books?hl=vi\&lr=\&id=AkZ9DAAAQBAJ\&oi=fnd\&pg=PP1 $\& d q=$ Trade + Union + of + Vietnam\&ots=r5p0rZhpn2\&sig=CJjK3YAKTxLXuvpHdubZbRDuQaA

25. Pringle T. (2013) Social Justice on the Shop Floor:Trade Union Reform in Russia, China and Vietnam. In: Howell J. (eds) Non-Governmental Public Action and Social Justice. Non-Governmental Public Action. Palgrave Macmillan, London. https://doi.org/10.1057/9781137309174_2

26. Shurcliff, A. W. (1951). Trade-Union Movement in Vietnam. Monthly Labor Review, 72(1), 30 33. http://www.jstor.org/stable/41832253

27. Chan, A. (2019). Vietnam has Ratified ILO C98. How about China?. International Union Rights, 26(3), 4-5. https://doi.org/10.14213/inteuniorigh.26.3.0004

28. Yuan-fu, WU. (2011). Current Situation of Vietnam Enterprises Labor Relations and Amendment of Trade Union Law. En.Cnki.Com.Cn. https://en.cnki.com.cn/Article_en/CJFDTotalHBFX201108024.htm

29. Kaxton Siu \& Anita Chan (2015) Strike Wave in Vietnam, 2006-2011, Journal of Contemporary Asia, 45(1), 71-91. https://doi.org/10.1080/00472336.2014.903290

30. Thi Tam, T. (2021). IMPACT OF CPTPP ON CHILD LABOUR IN VIET NAM AND THE ROLE OF SOCIAL WORK. International Journal of Social Science and Economic Research. 6(5). https://doi.org/10.46609/IJSSER.2021.v06i05.002

31. TRANSITION, W. D.-T. U. I. (2018). RUDOLF TRAUB-MERZ AND TIM PRINGLE (EDS) TRADE UNIONS IN TRANSITION FROM COMMAND TO MARKET ECONOMIES. In library.fes.de. https://library.fes.de/pdf-files/iez/14633.pdf\#page=149

32. Trinh, R., \& Kien, T. (2010). AN OVERVIEW OF VIETNAM LABOR LAW HIRING THE EMPLOYEE Main Sources of Employment Law Special Hiring Considerations Hiring NonNationals. tilleke.com. https://www.tilleke.com/wp-content/uploads/2011/05/Overview-ofVietnam-Labor-Law.pdf

33. Vo, A., Review, C. R.-A. P. B. (2010). The internationalization of industrial relations? Japanese and US multinational companies in Vietnam. Taylor \& Francis. https://www.tandfonline.com/doi/ abs/10.1080/13602380903080282

34. Zhu, Y., \& Fahey, S. (2000). The challenges and opportunities for the trade union movement in the transition era: Two socialist market economies China and Vietnam. Asia Pacific Business Review, 6(3-4 SPEC. ISS.), 298-299. https://doi.org/10.1080/13602380012331288572 